\title{
Review \\ Forensic Value of Genetic Variants Associated with Anti-Social Behavior
}

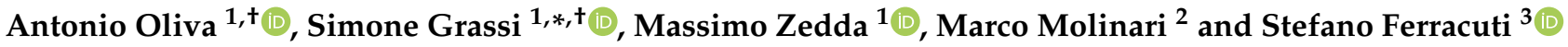 \\ 1 Department of Health Surveillance and Bioethics, Section of Legal Medicine, Fondazione Policlinico A. \\ Gemelli IRCCS, Università Cattolica del Sacro Cuore, Largo Francesco Vito 1, 00168 Rome, Italy; \\ antonio.oliva@unicatt.it (A.O.); massimo_zedda@icloud.com (M.Z.) \\ 2 Neuro-Robot Rehabilitation Lab, IRCCS Fondazione Santa Lucia, Via Ardeatina 306, 00179 Rome, Italy; \\ m.molinari@hsantalucia.it \\ 3 Department of Human Neuroscience, Sapienza University, Piazzale Aldo Moro 5, 00165 Rome, Italy; \\ stefano.ferracuti@uniroma1.it \\ * Correspondence: Simone.grassi@unicatt.it \\ + Antonio Oliva and Simone Grassi equally contributed and thus should be considered co-first authors.
}

Citation: Oliva, A.; Grassi, S.; Zedda, M.; Molinari, M.; Ferracuti, S. Forensic Value of Genetic Variants Associated with Anti-Social Behavior Diagnostics 2021, 11, 2386. https:// doi.org/10.3390/diagnostics11122386

Academic Editors: Hiroshi Ikegaya and Marco Di Paolo

Received: 29 November 2021 Accepted: 16 December 2021 Published: 17 December 2021

Publisher's Note: MDPI stays neutral with regard to jurisdictional claims in published maps and institutional affiliations.

Copyright: (c) 2021 by the authors. Licensee MDPI, Basel, Switzerland. This article is an open access article distributed under the terms and conditions of the Creative Commons Attribution (CC BY) license (https:// creativecommons.org/licenses/by/ $4.0 /)$.

\begin{abstract}
Insanity defense is sometimes invoked in criminal cases, and its demonstration is usually based on a multifactorial contribution of behavioural, clinical, and neurological elements. Neuroradiological evidence of structural alterations in cerebral areas that involve decision-making and moral reasoning is often accepted as a useful tool in these evaluations. On the other hand, the genetic predisposition to anti-social behavior is still controversial. In this paper, we describe two cases of violent crimes committed by young carriers of genetic variants associated with personality disorder; both the defendants claimed to be insane at the time of the crime. We discuss these cases and review the scientific literature regarding the relationship between legal incapacity/predisposition to criminal behavior and genetic mutations. In conclusion, despite some genetic variants being able to influence several cognitive processes (like moral judgement and impulse control), there is currently no evidence that carriers of these mutations are, per se, incapable of intentionally committing crimes.
\end{abstract}

Keywords: anti-social behavior; genetic predisposition; behavioral genetics; crime; legal capacity

\section{Introduction}

In criminal cases, a defense based on proving the insanity of the defendant at the time of the offence and thus the lack of his intent to commit the crime (also called in the United States "mens rea") can be invoked. The defendant can be found not guilty for reasons of insanity only if the mental incompetence caused by severely impairing neurobiological anomalies or disorders (e.g., schizophrenia) is proved, and there is a causal link between the criminal behavior and the mental illness. In the United States, neurobiological evidence is presented with this purpose in approximately $5-6 \%$ of murder trials and $25 \%$ of death penalty trials [1]. In these cases, a multifactorial contribution of genetic, neurological and environmental factors is often invoked [1]. In the United States, in about $15 \%$ of the judicial opinions in which neurobiological evidence is discussed, the defendant undergoes neuroradiological examination (about a fourth of these tests are performed through MRI or CT) [1]. Structural and/or functional anomalies can cause severe behavioral impairment that, in some cases, may can be considered to be a legal excuse. For example, structural alterations and functional impairments of prefrontal cortex (PFC) have been associated with antisocial and criminal behavior [2]. In particular, Choy et al. studied the influence of PFC activity on criminal behavior, finding that an increase of the perceptions of moral wrongfulness in aggressive acts could be achieved through transcranial electric stimulation [3]. Moreover, psychopathic offenders tend to have a reduced grey matter volume in the prefrontal and temporal cortex [4]. In adulthood, reduced amygdala volume has also been associated with increased risk of antisocial behavior [5]. Hence, proving 
congenital or acquired (e.g., substances-related) structural alterations of the brain that can severely impair the intent or knowledge of wrongdoing has a strong legal impact and scientific basis. On the other hand, the genetic predisposition to anti-social behavior is controversial [6-11].

In this paper, we describe two cases of violent crimes committed by young carriers of genetic variants associated with antisocial behavior. Both the defendants were affected by personality disorders and invoked an insanity defense. Our aim is to discuss these cases and review the scientific literature regarding the relationship between legal incapacity/predisposition to criminal behavior and genetic mutations.

\section{Cases}

\subsection{Case 1}

A young man was killed by a 30-year-old man after they had consumed alcohol and cocaine. The murderer claimed he was not capable when he committed the crime because he suffered from an alcohol-/drug-caused behavioral impairment producing neurological damage, having regularly consumed alcohol and drugs since the beginning of adolescence. In detail, he reported to have started habitually consuming alcohol, cannabis, cocaine and amphetamine when he was a teenager. The defendant also claimed to be predisposed to anti-social behavior because of genetic factors. Indeed, his forensic consultant performed a genetic testing on him focused on three genes (MAOA, COMT, SLC6A4), finding that he was a carrier of the polymorphisms of 5-HTTLPR (fragment $44 \mathrm{bp}-\mathrm{SS}$ genotype) and COMT (Leu136Leu) in homozygosity.

Hence, the court requested a team of forensic experts to assess the capacity of the defendant, performing toxicology testing and a complete neuropsychiatric evaluation.

\subsubsection{Toxicology Testing}

Toxicology testing was performed on urine (four days after the murder), saliva (two days after the murder), blood and pubic hair (10 days after the murder). In blood and saliva, it failed to find significant levels of drugs or alcohol, while in urine it detected benzoylecgoine (322 ng/mL). In the pubic hair, significant levels of cocaine $(141 \mathrm{ng} / \mathrm{mg})$, benzoylecgonine (21 ng/mg), and ethylglucuronide in concentration $>30 \mathrm{pg} / \mathrm{mg}$ were found.

\subsubsection{Clinical and Neuroradiological Evaluation}

A full clinical/neuropsychological examination was performed. No clinical signs of neurological impairment and no signs of alcohol-dependence were observed. A personality disorder not otherwise specified was diagnosed. 3-Tesla brain MRI and brain CT-PET were also performed. In MRI imaging, a decrease in cortical thickness with larger lateral ventricles, a statistically significant volumetric asymmetry of the amygdalae (the right amygdala was smaller than the left one) and a decreased volume of the right orbito-frontal cortex (OFC) (in comparison with the left one) were observed. No ischemic lesion or anomalies in the corona radiata and in the subtentorial/cerebellar area were found. PET-CT did not find any alteration of brain perfusion or metabolism.

\subsection{Case 2}

A 25-year-old man abducted, raped and robbed two women under the influence of alcohol in six months. He reported that his father often physically and psychologically abused him and his mother during his childhood and that a teenager raped him when he was a child. He was unschooled and few years before the rapes he was convicted for having stabbed a man who had insulted him. After having been released, he committed several burglaries. Moreover, he reported to have frequently beaten his wife and to have often fantasized about raping women since he was very young, even if he knew rape was illegal. Finally, he reported to have begun to consume alcohol during his childhood, albeit he never became an alcoholic.

Hence, the court requested a forensic psychiatrist to assess the capacity of the defendant. 


\section{Clinical Evaluation and Genetic Testing}

A full clinical/neuropsychological examination was performed. No clinical/ electroencephalographical signs of neurological impairment and no signs of alcohol-dependence were observed. An intelligence quotient (IQ) of 59 was found and an antisocial personality disorder was diagnosed. A genetic test focused on five genes (MAOA, COMT, SLC6A4, $H T R 1 B$, and $D R D 4$ ) found a 3-repeat variable number of tandem repeats (VNTR) variant of $M A O A$ and a TT genotype for the rs13212041 polymorphism of the HTR1B gene.

\section{Literature Review Methodology}

The aim of the review was to describe an overview of the available research evidence regarding the interpretation of the significance of genetic variants in the criminal justice system, focusing on the behavioral aspects. Two investigators searched published studies through the electronic database MEDLINE via PubMed. Two search strings were used, combining couples of keywords through the Boolean operator AND: (1) "(gene) AND (criminal justice)" and (2) "(behavioral genetics) AND (criminal justice)". The eligibility criteria were: publication date between 1 January 1995 and 12 December 2021; English language. The first search string produced 231 results, while the second search string produced 128 results. The results were compared, finding 50 overlapping papers. The investigators examined the titles and abstracts of the 309 papers, excluding 177 results because they did not fall within the review objective. Therefore, the full texts of the remaining papers were carefully read. Nine papers were excluded because they were not written in English. The final output of the review process consisted of 82 papers (cited in the bibliography).

\section{Discussion}

Case 1 committed a murder under the influence of cocaine and alcohol and defended himself claiming to be incapable of his actions because of a long history of alcohol and drug abuse which started at a very young age. No elements of toxicological, clinical or radiological signs supported the thesis of the defendant, concluding that he was affected by a personality disorder not otherwise specified.

Case 2 abducted, raped and robbed two women under the influence of alcohol and claimed to be incapable of committing the crimes. He neither reported nor showed signs of alcohol dependence and was found to be affected by an antisocial personality disorder.

Under Italian law, having committed a crime under the influence of drugs and/or alcohol does not affect legal capacity unless it is proven that the chronic consumption of illicit substances completely impaired his intent or knowledge of wrongdoing because of a severe organic dysfunction (art. 95 of the Italian criminal code). More specifically, the defendant can be found not responsible only if he proves that his mental state and/or his congenital/acquired behavioral anomalies annihilated the capacity of intending his actions. Furthermore, if the mental impairment was due to the intake of alcohol or illicit drugs, it must also be proved that the substances caused severe chronic structural damage. Hence, being the defendants theses of the described cases based only on their genetic predisposition to anti-social behavior, they were judged legally competent. Both the cases presented no signs of chronic brain damage caused by alcohol or drugs, thus their capacity to control their impulses and understand the significance and the consequences of their actions were considered substantially intact. Moreover, Case 2 had a personal history of physical, psychological and sexual abuse during childhood and, when he committed crimes, showed patterns of conscious criminal intent (e.g., he abducted the victims to rape them without being interrupted and then he took their valuables). Therefore, in Case 2 the role of genetic factors was considered marginal at most, even if the subject had a combination of polymorphisms that is described as a predisposing factor for violent and impulsive behavior.

Farahani et al. observed that in these cases the main limitation of neurobiological evidence, and in particular of genetic evidence, is represented by the fact that, while 
these investigations are relatively expensive, their influence over the judge's decision is unpredictable [1]. In particular, a line of defense only based on genetic evidence is rarely used because it is almost always unsuccessful $[12,13]$. On the contrary, the combination of genetic evidence and environmental factors predisposing to anti-social behavior (like maltreatment, maternal disengagement and poor school performance during childhood and drug abuse) can lead to a recognition of mitigating circumstances [14-18]. The supporters of behavioral genetics often observe that there is also a sort a familiarity for anti-social behavior and that there are congenital anomalies that seem to predispose to criminal activities. Regarding the role of family environment, many authors reported that the criminal behavior of the parents is associated with a higher risk of their children committing crimes, even if they are adopted by parents without a criminal record [19,20]. For example, Beaver reported that the adoptees with at least a biological parent who had been arrested were at higher risk of committing crimes (OR if only a parent had been arrested: 3.25-6.58; OR if both parents had been arrested 4.73-12.87) [19]. Moreover, Wertz et al. found that monozygotic twins were more similar in their criminal offending than dizygotic twins [21]. Regarding congenital structural alterations, anomalies of prefrontal cortex, amygdala and striatum are considered to be potentially involved in criminal behavior, and some genetic variants have been associated with these alterations (for example, low MAOA expression has been associated with a reduction in the size of limbic system) [2,22]. However, this kind of genetic polymorphism does not always correspond to structural anomalies.

\section{1. $M A O A$}

The $M A O A$ gene (also called the "warrior gene") encodes the mono-amine oxidase A, that deactivates monoamine neurotransmitters like dopamine, norepinephrine and serotonin [8,23]. MAOA is highly expressed in PFC and under expressed in the hypothalamus [22,24]. The low-activity 2- or 3-repeat variants of $M A O A$ are known as $M A O A-L$ and have been associated with impulsivity and antisocial behavior [8]. In particular, carriers of $M A O A-L$ often fail to manage strong emotional impulses [21]. Stetler et al. found a statistically significant association between $M A O A-L$ VNTR alleles and violent crime in Caucasians $(p<0.01)$ but not in African Americans $(p=0.08)$ [25]. Since the MAOA gene is in chromosome $\mathrm{X}$, supposedly women are less inclined to antisocial behavior [22]. According to Caspi et al., children with a history of abuse and $M A O A-H$ (high activity) genotype had a lower risk of developing antisocial behavior [7]. Despite this, the long four repeat allele of $M A O A$ gene $(M A O A-H)$ is associated with criminal behavior in female adolescents with psychosocial risk [26]. This is a controversial topic because in women one of the two X chromosomes (and then one of the MAOA allele) is inactivated and therefore in heterozygotes can be difficult to associate the phenotype with the exact genotype [27].

Armstrong et al. found an association between $M A O A-L$ genotype and criminal behavior $(p=0.038)$ and between MAOAL genotype and property crime arrest $(p=0.039)$ [28]. Beaver et al. reported that $M A O A-L$ can increase the risk of becoming a gang member and weapon use by, respectively, 1.94 times and 1.82 times [29]. The interaction between $M A O A$ $L$ and family environment has been studied by many authors. For example, Gonzalez-Tapia et al. found that carriers of $M A O A-L$ who were victims of childhood maltreatment tended to show a reduction of PFC volume [8]. Fergusson et al. reported that in MAOA-L carriers there can be a relationship between criminal behavior, low IQ and family-related factors like maternal smocking during the pregnancy and childhood maltreatment [30]. On the basis of the different number of repeats, $M A O A-L$ may have different effects. The 2-repeat allele of $M A O A-L$ was associated with shooting and stabling $(p=0.05)$ and with the total number of shooting and stabling accidents $(p=0.05)$ [31]. In heroin addicts, the frequency of low activity 3-repeats $M A O A-L$ allele was significantly higher in violent offenders $(p=0.03)$ [32]. Violent antisocial offenders had more frequently the 3-repeat allele of $M A O A-L(p=0.05)$ [32]. While most of the evidence is focused on $M A O A-L$, even the high-activity variants of $M A O A$ have been associated with anti-social behavior. For example, the high-activity 4-repeat allele is reportedly more frequent in heroin addicts without a 
history of violence or crime $(p=0.02)$ [32]. Moreover, high-activity variants can increase the risk of fraudulent behavior in young males with several delinquent peers [33]. Finally, it should be noted that some authors confuted the hypothesis of the criminogenic role of $M A O A$. For example, Lu-Menard et al. did not find a clear and statistically significant relationship between $M A O A-L$ and delinquent peer affiliation or criminal conduct [6].

\subsection{5-HTT}

The serotoninergic system plays a major role in the regulation of emotions such as fear, anger and anxiety [34]. Toshchakova et al. found a statistically significant association between criminal behavior and polymorphisms of 5HTTLPR (a region inside the geneSLC6A4-that codes for serotonin transporter) $(p=0.004)$ and 5HTR2C (that codes for a subtype of serotonin receptor) $(p=0.0026)$ [35]. Liao et al. have found a statistically significant association between violent behavior and the presence of a low-activity short allele of 5HTTLPR $(p=0.006)$ [36]. In neglected females, the homozygosity for the short allele of 5-HTTLPR has also been associated with an increased risk of cannabis abuse [37]. The SS (short-short) allele of 5HTTLPR has been associated with aggressive behavior and mood disorders [38]. Gerra et al. found that, in heroin-addicted males, the SS allele is overexpressed and associated with violent behavior $(p=0.02)$ [39]. Even the LL (longlong) variant of $5 H T T L P R$ has been reported to increase the risk of criminal behavior (in males with low socioeconomic status) [40]. Berggard et al. studied the 5-HT2A-1438 GA polymorphism in a sample of 97 Swedish imprisoned criminal men and 202 non-criminal controls. The authors found a lower rate of the 5-HT2A-1438 GG genotype in the criminal group ( $p=0.034$ ) [41]. The HTR1B gene codes for the serotonin receptor $1 \mathrm{~B}$, that inhibits the release of 5-HTT in the synapsis [42]. Pauwels et al. found that HTR1B gene can interact with dopaminergic, glutamatergic, gamma-aminobutyric and cholinergic receptors [43]. The interaction between microRNA and specific DNA sequences can modulate the gene expression. Some studies found a sequence in the $3^{\prime}$ UTR of HTR1B gene (rs13212041) that promotes the link with a specific microRNA (miR-96), and this interaction seems to be associated with violent behavior $[44,45]$. Furthermore, the same authors found that the TT genotype of rs13212041 polymorphism was related to anger and hostility [44,45].

\subsection{COMT}

The dopamine system is regulated by different catabolic enzymes including the catechol-O methyltransferase (encoded by the COMT gene) [46]. Both hyperdopaminergic and hypodopaminergic stimulations have been associated with abnormal functioning of the PFC [47]. The Val158Met polymorphism is the most discussed in scientific literature. According to Caspi et al., homozygosity for the Val allele is more frequently associated with conduct disorder than the Met variant, and it increases the risk of aggressive behavior in young men with attention deficit hyperactivity disorder (ADHD) [48]. Schizophrenic men with at least a Met allele had a risk of violent behavior increased by $50 \%$ than men with Val allele in homozygosity [49].

\subsection{DAT-1}

DAT-1 (also known as SLC6A3) encodes the dopamine transporter protein, that regulates the level of intra-synaptic dopamine and the dopamine receptor activation [50]. Some authors found an association between criminal behavior and the number of repeats of DAT1 [51]. Siblings with a 10-repeat allele had a higher risk of being arrested than the siblings with a 9-repeat allele [52]. The 9-9 genotype is associated with a level of irritability and aggressiveness ten times higher than the 9-10 genotype [53]. Beaver et al. found that the 10-repeat DAT1 was associated with self-reported delinquent peer affiliation in adolescents with environmental risk factors [51]. In a population of 2380 respondents, Vaske et al. found that a 10-repeat allele increases the risk of alcohol use disorder in young men with alcoholic fathers, while the 9-repeat allele was directly related to the risk of alcohol problems in young females (independently from the condition of the father) [54]. Males with 2- or 
3-repeat allele of $M A O A$ and 10-repeat allele of DAT1 in homozygosity had less self-control and an increased risk of criminal behavior [55]. In young males DAT1 polymorphisms have also been related to promiscuous sexual behavior and criminal activity [56].

\subsection{DRD2 and DRD4}

Polymorphisms of the dopamine receptor D2 (DRD2) and dopamine receptor D4 (DRD4) are thought to influence human behavior [57]. In 2007, studying a population of 872 males, Beaver et al. found an association between DRD2/DRD4 and conduct disorder [58]. However, in 2009 the same research group reported that the A1 allele of DRD2 did not predispose to criminal behavior [59]. Boutwell et al. found that carriers of 7-repeat allele of DRD4 and A1 allele of DRD2 were more likely to commit major theft, burglary and gang fights [60]. In another study, Boutwell et al. found that persons with few DRD4 allele repetitions were less likely to be involved in criminal behavior, meaning that DRD4 had a positive association with non-abstention in delinquency [61]. Cherepkova et al. reported a higher frequency of $D R D 47$-repeat allele in criminal offenders and in mixed martial arts fighters without criminal record [62].

\subsection{GABBR2}

The GABBR2 gene encodes a subunit of the receptor of gamma-aminobutyric acid, the most important inhibitory neurotransmitter in the human brain [63]. Terranova et al. compared two study populations: 47 persons with a criminal record and 139 persons without criminal record. They found that the SNP rs3780428 (situated in the intronic region of the GABBR2) had a statistically significant association with the first group ( $p=0.0067)$ [18].

\section{7. $B D N F$}

The BDNF gene encodes a neurotrophic factor involved in synaptic plasticity [64]. According to some authors, abnormal synaptic plasticity may increase the risk of aggressive and antisocial behavior [8]. In particular, a polymorphism (Val66Met) has been reported to potentially predispose to crime [65]. Matsushita et al. reported that, despite the genotype and allele distributions of this polymorphism not significantly differing between alcoholic and control cases, alcoholic persons with aggressive behavior and a history of delirium tremens had a significantly higher frequency of AA genotypes [66]. In a sample of 392 subjects with criminal record, Bresin et al. found a relationship between homozygosity for the Val allele of the BDNF Val66Met polymorphism and self-injurious behavior. Moreover, the authors did not find any association between these variables and the Met allele [67].

\subsection{NOS-1}

The NOS-1 gene normally contributes to regulate the inflammatory response [68]. Retz et al. found a statistically significant association between NOS1 ex1f-VNTR and self-reported impulsiveness $(p=0.0052)$ [69]. Other authors have studied the association between short (182 repeats)/intermediate (192 repeats)/long (204 repeats) variants of NOS1 Exlf-VNTR and impulsivity or aggressive behavior, finding that in the adults the short variant was associated with attention deficit hyperactivity disorder, cluster B personality disorder and aggressive behavior [67]. Reif et al. found that the short variant of NOS1 Exlf VNTR (associated with a low activity of the NOS1 exon lf promoter), was related to reduced activity of the anterior cingulate cortex, a brain area involved in the emotional process [70]. Furthermore, Reif et al. found an association between the short variant of NOS1 Exlf VNTR and hypoactivation of anterior cingulate cortex [70].

\subsection{Y Chromosome and Androgens}

The role play by the $\mathrm{Y}$ chromosome and androgens in criminal behavior is unclear. The presence of DYS533 allele 14 and DYS437 allele 14 (two short tandem repeats loci of Y chromosome) increases the risk of aggressive behavior. Conversely, the DYS437 allele 
15 frequency was higher in persons without a history of criminal behavior [71]. Furthermore, some authors found that the short trinucleotide repeat polymorphism in the $A R$ (androgen receptor) gene was associated with violent-criminal behavior [72]. Concerning the role of the androgens in criminal behavior, Sjoberg et al. found that those suffering from an antisocial personality disorder had a significantly increased level of testosterone in the cerebrospinal fluid $(p=0.008)$. Moreover, the authors found a significative high level of testosterone in cerebrospinal fluid of persons with $M A O A-L$ genotype and diagnosis of antisocial personality disorder $(p=0.001)$ [73].

\subsection{ZNF}

Genes encoding zinc finger proteins (ZNF) have also been associated with abnormal and/or criminal behavior. For example, some polymorphisms of ZNF804A gene have been associated with drug abuse in European Americans, while Tiihonen et al. reported that, in the brains of violent offenders, ribosomal pseudogene RPL10P9 and ZNF132 were upregulated [74,75].

\subsection{Other Genes}

As said, alterations of the serotoninergic and dopaminergic systems may be associated with criminal or violent behavior. Annebrink et al. found a relationship between $A C E I / D$ (Angiotensin Converting Enzyme Insertion/Deletion) polymorphism and the CSF (cerebrospinal fluid) level of serotonin and dopamine metabolites, respectively 5hydroxyindoleacetic acid and homovanillic acid [76]. Regarding the role of the PFC in the development of aggressive behavior, Konar et al. reported an increased expression of the proto-oncogene C-FOS in the PFC cortex of animal with hyper-responsive behavior [24]. The CRHR1 gene is considered to be involved in the responses to stressful events through the activation of the limbic system [77]. Chen et al. found a higher rate of intentional injuries among the carriers of the haplotype H3 (GGA) of the CRHR1 gene [78]. Furthermore, regarding the hypothalamic-pituitary-adrenal axis in the development of criminal behavior, some authors found that some corticotropin releasing hormone binding protein (CRHBP) haplotypes (rs10062367G, rs32897T, rs7718461A, and rs7721799G) in association with rs32897 T allele caused an increased risk of robbery behavior $(p=0.0213)$ [79]. The development of anti-social (aggressive) behavior can also be related to epigenetic factors: for instance, an increased methylation of OXTR (oxytocin receptor gene) has been associated with callous-unemotional traits and aggressive behavior [80]. Tiihonen et al. found that $30-92 \%$ of the hardness of psychopathy is related to the levels of the expression of RPL109 (Ribosomial Protein L109), ZNF132 (Zinc finger 132), CDH5 (Cadherin 5) and OPRD1 (Opioid Receptor Delta 1) genes [75].

\section{Conclusions}

We started our discussion with the presentation of two cases. In the first, a 5-HTTLPR SS genotype and a variant of COMT (Leu136Leu) in homozygosity were found. In particular, variants of 5-HTTLPR have been associated with behavioral anomalies (e.g., emotional dysregulation), while the specific COMT polymorphism that was found (Leu136Leu) is not well-known in the scientific literature regarding this matter, since the COMT variant generally associated with aggressive behavior is Val158Met.

The second case presented a 3-repeat VNTR variant of $M A O A$ and a TT genotype for the rs13212041 polymorphism of the HTR1B gene, that have been associated with aggressive behavior.

In both the cases, the courts did not consider the genetic findings as evidence of mental incapacity because in scientific literature they have been associated with an abnormal impulse control but none of the crimes was impulsive. Therefore, genetic variations were not considered relevant to the issue of deliberate intent.

As shown by the review of the literature, the relationship between genetic variants and anti-social behavior is often based on case-control studies. Most of the authors agree on the 
importance of the combination of genetic predisposition and social/family environment and none of the discussed evidence proves that the carriers of these mutations are per se incapable of intentionally committing crimes. However, genetic variants are proved to influence several cognitive processes (like moral judgement and impulse control) and, in combination with neuroradiological evidence, environmental factors and psychiatric disorders, can impair the intent, and thus the willfulness and malice aforethought, to commit a crime [27,81].

As observed by many authors, emphasizing the possible criminogenic significance of some of these variants could be a double-edged sword in the legal field [82]. Indeed, wrongfully believing in a deterministic relationship between some genetic variants and crime would expose the carriers to the risk of social and legal stigma, being considered as latent criminals [83].

In conclusion, albeit genetic analysis in these cases may lead to important evidence, it is always important not to consider genetic variants as the sole determinants of anti-social conduct, and in these cases a comprehensive and multidisciplinary approach should always be adopted $[84,85]$.

Author Contributions: A.O. and S.F. conceived and designed the project; A.O., S.F. and M.M. selected and presented the cases; S.G. and M.Z. reviewed the literature; all the authors contributed in writing the paper. All authors have read and agreed to the published version of the manuscript.

Funding: This work has been supported by Fondi di Ateneo, Linea D1-Università Cattolica del Sacro Cuore, grant no. R4124500772, to Antonio Oliva.

Institutional Review Board Statement: Ethical review and approval were waived for this study, because the review did not request to perform experimentations on humans or animals.

Informed Consent Statement: Patient consent was waived in compliance with the General Data Protection Regulation (EU) 2016/679 regarding the use for scientific research of anonymized data lawfully processed and concerning dismissed judicial cases.

Data Availability Statement: The data presented in this study are available on request from the corresponding author.

Conflicts of Interest: All authors certify that they have no affiliations with or involvement in any organization or entity with any financial interest or non-financial interest in the subject matter or materials discussed in this manuscript.

\section{References}

1. Farahany, N.A. Neuroscience and behavioral genetics in US criminal law: An empirical analysis. J. Law Biosci. 2016, 2, 485-509. [CrossRef] [PubMed]

2. Ling, S.; Umbach, R.; Raine, A. Biological explanations of criminal behavior. Psychol. Crime Law 2019, 25, 626-640. [CrossRef]

3. Choy, O.; Raine, A.; Hamilton, R.H. Stimulation of the Prefrontal Cortex Reduces Intentions to Commit Aggression: A Randomized, Double-Blind, Placebo-Controlled, Stratified, Parallel-Group Trial. J. Neurosci. 2018, 38, 6505-6512. [CrossRef] [PubMed]

4. Gregory, S.; Ffytche, D.; Simmons, A.; Kumari, V.; Howard, M.; Hodgins, S.; Blackwood, N. The Antisocial Brain: Psychopathy Matters: A structural mri investigation of antisocial male violent offenders. Arch. Gen. Psychiatry 2012, 69, 962-972. [CrossRef]

5. Pardini, D.A.; Raine, A.; Erickson, K.; Loeber, R. Lower Amygdala Volume in Men is Associated with Childhood Aggression, Early Psychopathic Traits, and Future Violence. Biol. Psychiatry 2014, 75, 73-80. [CrossRef] [PubMed]

6. Lu, Y.-F.; Menard, S. The Interplay of MAOA and Peer Influences in Predicting Adult Criminal Behavior. Psychiatr. Q. 2017, 88, 115-128. [CrossRef]

7. Caspi, A.; McClay, J.; Moffitt, T.E.; Mill, J.; Martin-Moreno, L.; Craig, I.W.; Taylor, A.; Poulton, R. Role of Genotype in the Cycle of Violence in Maltreated Children. Science 2002, 297, 851-854. [CrossRef]

8. González-Tapia, M.I.; Obsuth, I. “Bad genes” \& criminal responsibility. Int. J. Law Psychiatry 2015, 39, 60-71. [CrossRef]

9. Ferguson, C.J. Genetic Contributions to Antisocial Personality and Behavior: A Meta-Analytic Review from an Evolutionary Perspective. J. Soc. Psychol. 2010, 150, 160-180. [CrossRef]

10. Gard, A.M.; Dotterer, H.L.; Hyde, L.W. Genetic influences on antisocial behavior: Recent advances and future directions. Curr. Opin. Psychol. 2019, 27, 46-55. [CrossRef]

11. Nilsson, K.W.; Åslund, C.; Comasco, E.; Oreland, L. Gene-environment interaction of monoamine oxidase A in relation to antisocial behaviour: Current and future directions. J. Neural Transm. 2018, 125, 1601-1626. [CrossRef] [PubMed] 
12. Segal, J.B. Inherited proclivity: When should neurogenetics mitigate moral culpability for purposes of sentencing? J. Law Biosci. 2016, 3, 227-237. [CrossRef] [PubMed]

13. McSwiggan, S.; Elger, B.; Appelbaum, P.S. The forensic use of behavioral genetics in criminal proceedings: Case of the MAOA-L genotype. Int. J. Law Psychiatry 2017, 50, 17-23. [CrossRef] [PubMed]

14. Sabatello, M.; Appelbaum, P.S. Behavioral Genetics in Criminal and Civil Courts. Harv. Rev. Psychiatry 2017, 25, 289-301. [CrossRef]

15. Scurich, N.; Appelbaum, P.S. Behavioral Genetics in Criminal Court Nicholas. Physiol. Behav. 2017, 176, 139-148. [CrossRef]

16. Boutwell, B.B.; Beaver, K.M.; Barnes, J.C.; Vaske, J. The developmental origins of externalizing behavioral problems: Parental disengagement and the role of gene-environment interplay. Psychiatry Res. 2012, 197, 337-344. [CrossRef] [PubMed]

17. Young, S.E.; Smolen, A.; Hewitt, J.K.; Haberstick, B.C.; Stallings, M.C.; Corley, R.P.; Crowley, T.J. Interaction Between MAO-A Genotype and Maltreatment in the Risk for Conduct Disorder: Failure to Confirm in Adolescent Patients. Am. J. Psychiatry 2006, 163, 1019-1025. [CrossRef]

18. Terranova, C.; Tucci, M.; Sartore, D.; Cavarzeran, F.; Di Pietra, L.; Barzon, L.; Palù, G.; Ferrara, S.D. GABA Receptors, Alcohol Dependence and Criminal Behavior. J. Forensic Sci. 2013, 58, 1227-1232. [CrossRef]

19. Beaver, K.M. Genetic Influences on Being Processed Through the Criminal Justice System: Results from a Sample of Adoptees. Biol. Psychiatry 2011, 69, 282-287. [CrossRef]

20. Kendler, K.S.; Lönn, S.L.; Morris, N.A.; Sundquist, J.; Långström, N. A Swedish national adoption study of criminality. Psychol. Med. 2014, 44, 1913-1925. [CrossRef] [PubMed]

21. Wertz, J.; Caspi, A.; Belsky, D.W.; Beckley, A.; Arseneault, L.; Barnes, J.C.; Corcoran, D.L.; Hogan, S.; Houts, R.; Morgan, N.; et al Genetics and Crime: Integrating New Genomic Discoveries Into Psychological Research About Antisocial Behavior. Psychol. Sci. 2018, 29, 791-803. [CrossRef] [PubMed]

22. Hunter, P. The psycho gene. EMBO Rep. 2010, 11, 667-669. [CrossRef]

23. Kravic, N.; Dzananovic, E.S.; Umihanic, M.M.; Kulenovic, A.D.; Sinanovic, O.; Jakovljevic, M.; Babic, D.; Kucukalic, A.; Agani, F.; Kucukalic, S.; et al. Association Analysis of Maoa And Slc6a4 Gene Variation in South East European War Related Posttraumatic Stress Disorder. Psychiatr. Danub. 2019, 31, 211-218. [CrossRef] [PubMed]

24. Konar, A.; Rastogi, M.; Bhambri, A. Brain region specific methylation and Sirt1 binding changes in MAOA promoter is associated with sexual dimorphism in early life stress induced aggressive behavior. Neurochem. Int. 2019, 129, 104510. [CrossRef] [PubMed]

25. Stetler, D.A.; Davis, C.; Leavitt, K.; Schriger, I.; Benson, K.; Bhakta, S.; Wang, L.C.; Oben, C.; Watters, M.; Haghnegahdar, T.; et al. Crime in Incarcerated Offenders. J. Psychiatr. Res. 2014, 58, 69-75. [CrossRef]

26. Sjöberg, R.L.; Nilsson, K.W.; Wargelius, H.-L.; Leppert, J.; Lindström, L.; Oreland, L. Adolescent girls and criminal activity: Role of MAOA-LPR genotype and psychosocial factors. Am. J. Med. Genet. Part B Neuropsychiatr. Genet. 2007, 144B, 159-164. [CrossRef]

27. Rigoni, D.; Pellegrini, S.; Mariotti, V.; Cozza, A.; Mechelli, A.; Ferrara, S.D.; Pietrini, P.; Sartori, G. How Neuroscience and Behavioral Genetics Improve Psychiatric Assessment: Report on a Violent Murder Case. Front. Behav. Neurosci. $2010,4,160$. [CrossRef]

28. Armstrong, T.A.; Boutwell, B.B.; Flores, S.; Symonds, M.; Keller, S.; Gangitano, D.A. Monoamine oxidase A genotype, childhood adversity, and criminal behavior in an incarcerated sample. Psychiatr. Genet. 2014, 24, 164-171. [CrossRef] [PubMed]

29. Beaver, K.M.; DeLisi, M.; Vaughn, M.G.; Barnes, J. Monoamine oxidase A genotype is associated with gang membership and weapon use. Compr. Psychiatry 2010, 51, 130-134. [CrossRef]

30. Fergusson, D.M.; Boden, J.M.; Horwood, L.J.; Miller, A.; Kennedy, M.A. Moderating role of the MAOA genotype in antisocial behaviour. Br. J. Psychiatry 2012, 200, 116-123. [CrossRef]

31. Beaver, K.M.; Barnes, J.C.; Boutwell, B.B. The 2-Repeat Allele of the MAOA Gene Confers an Increased Risk for Shooting and Stabbing Behaviors. Psychiatr. Q. 2014, 85, 257-265. [CrossRef]

32. Bosari, S.; Bussandri, M.; Moi, A.; Brambilla, F.; Mameli, A.; Pizzamiglio, M.; Donnini, C.; Moi, G.; Gerra, G.; Garofano, L.; et al Analysis of monoamine oxidase A (MAO-A) promoter polymorphism in male heroin-dependent subjects: Behavioural and personality correlates. J. Neural Transm. 2004, 111, 611-621. [CrossRef]

33. Beaver, K.M.; Holtfreter, K. Biosocial Influences on Fraudulent Behaviors. J. Genet. Psychol. 2009, 170, 101-114. [CrossRef] [PubMed]

34. Lagoa, A.; Santos, A.; Pinheiro, M.F.; Magalhães, T. Genetics and criminal behaviour: Recent accomplishments. Med. Sci. Law 2009, 49, 274-282. [CrossRef]

35. Toshchakova, V.A.; Bakhtiari, Y.; Kulikov, A.V.; Gusev, S.I.; Trofimova, M.V.; Fedorenko, O.Y.; Mikhalitskaya, E.V.; Popova, N.K.; Bokhan, N.; Hovens, J.E.; et al. Association of Polymorphisms of Serotonin Transporter (5HTTLPR) and 5-HT2C Receptor Genes with Criminal Behavior in Russian Criminal Offenders. Neuropsychobiology 2018, 75, 200-210. [CrossRef]

36. Liao, D.-L.; Hong, C.-J.; Shih, H.-L.; Tsai, S.-J. Possible Association between Serotonin Transporter Promoter Region Polymorphism and Extremely Violent Crime in Chinese Males. Neuropsychobiology 2004, 50, 284-287. [CrossRef]

37. Vaske, J.; Newsome, J.; Wright, J.P. Interaction of serotonin transporter linked polymorphic region and childhood neglect on criminal behavior and substance use for males and females. Dev. Psychopathol. 2012, 24, 181-193. [CrossRef]

38. Tatarelli, R.; Del Casale, A.; Tatarelli, C.; Serata, D.; Rapinesi, C.; Sani, G.; Kotzalidis, G.D.; Girardi, P. Behavioral genetics and criminal responsibility at the courtroom. Forensic Sci. Int. 2014, 237, 40-45. [CrossRef] [PubMed] 
39. Gerra, G.; Garofano, L.; Santoro, G.; Bosari, S.; Pellegrini, C.; Zaimovic, A.; Moi, G.; Bussandri, M.; Moi, A.; Brambilla, F.; et al. Association between low-activity serotonin transporter genotype and heroin dependence: Behavioral and personality correlates. Am. J. Med. Genet. 2004, 126B, 37-42. [CrossRef] [PubMed]

40. Azeredo, A.; Moreira, D.; Figueiredo, P.; Barbosa, F. Delinquent Behavior: Systematic Review of Genetic and Environmental Risk Factors. Clin. Child Fam. Psychol. Rev. 2019, 22, 502-526. [CrossRef]

41. Berggård, C.; Damberg, M.; Longato-Stadler, E.; Hallman, J.; Oreland, L.; Garpenstrand, H. The serotonin 2A -1438 G/A receptor polymorphism in a group of Swedish male criminals. Neurosci. Lett. 2003, 347, 196-198. [CrossRef]

42. Hoyer, D.; Hannon, J.P.; Martin, G.R. Molecular, pharmacological and functional diversity of 5-HT receptors. Pharmacol. Biochem. Behav. 2002, 71, 533-554. [CrossRef]

43. Pauwels, P.J. 5-HT1BD receptor antagonists. Gen. Pharmacol. Vasc. Syst. 1997, 29, 293-303. [CrossRef]

44. Jensen, K.P.; Covault, J.; Conner, T.S.; Tennen, H.; Kranzler, H.R.; Furneaux, H.M. A common polymorphism in serotonin receptor 1B mRNA moderates regulation by miR-96 and associates with aggressive human behaviors. Mol. Psychiatry 2009, 14, 381-389. [CrossRef] [PubMed]

45. Conner, T.S.; Jensen, K.P.; Tennen, H.; Furneaux, H.M.; Kranzler, H.R.; Covault, J. Functional polymorphisms in the serotonin 1B receptor gene (HTR1B) predict self-reported anger and hostility among young men. Am. J. Med. Genet. Part B Neuropsychiatr. Genet. 2010, 9999B, 67-78. [CrossRef] [PubMed]

46. Pigoni, A.; Lazzaretti, M.; Mandolini, G.; Delvecchio, G.; Altamura, A.; Soares, J.C.; Brambilla, P. The impact of COMT polymorphisms on cognition in Bipolar Disorder: A review. J. Affect. Disord. 2019, 243, 545-551. [CrossRef]

47. Fallon, S.J.; Williams-Gray, C.H.; Barker, R.A.; Owen, A.M.; Hampshire, A. Prefrontal Dopamine Levels Determine the Balance between Cognitive Stability and Flexibility. Cereb. Cortex 2013, 23, 361-369. [CrossRef] [PubMed]

48. Caspi, A.; Langley, K.; Milne, B.; Moffitt, T.E.; O’Donovan, M.; Owen, M.J.; Tomas, M.P.; Poulton, R.; Rutter, M.; Taylor, A.; et al. A Replicated Molecular Genetic Basis for Subtyping Antisocial Behavior in Children with Attention-Deficit/Hyperactivity Disorder. Arch. Gen. Psychiatry 2008, 65, 203-210. [CrossRef]

49. Singh, J.P.; Volavka, J.; Czobor, P.; Van Dorn, R.A. A Meta-Analysis of the Val158Met COMT Polymorphism and Violent Behavior in Schizophrenia. PLoS ONE 2012, 7, e43423. [CrossRef]

50. Qadeer, M.I.; Amar, A.; Mann, J.J.; Hasnain, S. Polymorphisms in dopaminergic system genes; association with criminal behavior and self-reported aggression in violent prison inmates from Pakistan. PLoS ONE 2017, 12, e0173571. [CrossRef]

51. Beaver, K.M.; Wright, J.P.; DeLisi, M. Delinquent Peer Group Formation: Evidence of a Gene X Environment Correlation. J. Genet. Psychol. 2008, 169, 227-244. [CrossRef]

52. Schwartz, J.A.; Beaver, K.M. Exploring whether genetic differences between siblings explain sibling differences in criminal justice outcomes. Compr. Psychiatry 2014, 55, 93-103. [CrossRef] [PubMed]

53. Gerra, G.; Garofano, L.; Pellegrini, C.; Bosari, S.; Zaimovic, A.; Moi, G.; Avanzini, P.; Talarico, E.; Gardini, F.; Donnini, C. Allelic association of a dopamine transporter gene polymorphism with antisocial behaviour in heroin-dependent patients. Addict. Biol. 2005, 10, 275-281. [CrossRef]

54. Vaske, J.; Beaver, K.M.; Wright, J.P.; Boisvert, D.; Schnupp, R. An interaction between DAT1 and having an alcoholic father predicts serious alcohol problems in a sample of males. Drug Alcohol Depend. 2009, 104, 17-22. [CrossRef]

55. Watts, S.J.; McNulty, T.L. Genes, Parenting, Self-Control, and Criminal Behavior. Int. J. Offender Ther. Comp. Criminol. 2016, 60, 469-491. [CrossRef]

56. Beaver, K.M.; Wright, J.P.; Walsh, A. A gene-based evolutionary explanation for the association between criminal involvement and number of sex partners. Biodemogr. Soc. Biol. 2008, 54, 47-55. [CrossRef] [PubMed]

57. Abrahams, S.; McFie, S.; Lacerda, M.; Patricios, J.; Suter, J.; September, A.V.; Posthumus, M. Unravelling the interaction between theDRD2andDRD4genes, personality traits and concussion risk. BMJ Open Sport Exerc. Med. 2019, 5, e000465. [CrossRef]

58. Beaver, K.M.; Wright, J.P.; DeLisi, M.; Walsh, A.; Vaughn, M.G.; Boisvert, D.; Vaske, J. A gene $\times$ gene interaction between DRD2 and DRD4 is associated with conduct disorder and antisocial behavior in males. Behav. Brain Funct. 2007, 3, 30. [CrossRef] [PubMed]

59. Beaver, K.M.; Gibson, C.L.; Jennings, W.G.; Ward, J.T. A gene X environment interaction between DRD2 and religiosity in the prediction of adolescent delinquent involvement in a sample of males. Biodemogr. Soc. Biol. 2009, 55, 71-81. [CrossRef]

60. Boutwell, B.B.; Menard, S.; Barnes, J.; Beaver, K.M.; Armstrong, T.A.; Boisvert, D. The role of gene-gene interaction in the prediction of criminal behavior. Compr. Psychiatry 2014, 55, 483-488. [CrossRef]

61. Boutwell, B.B.; Beaver, K.M. A biosocial explanation of delinquency abstention. Crim. Behav. Ment. Health 2008, 18, 59-74. [CrossRef]

62. Cherepkova, E.V.; Maksimov, V.N.; Kushnarev, A.P.; Shakhmatov, I.I.; Aftanas, L.I. The polymorphism of dopamine receptor D4 (DRD4) and dopamine transporter (DAT) genes in the men with antisocial behaviour and mixed martial arts fighters. World J. Biol. Psychiatry 2019, 20, 402-415. [CrossRef] [PubMed]

63. Petroff, O.A.C. GABA and glutamate in the human brain. Neuroscientist 2002, 8, 562-573. [CrossRef]

64. Lu, B.; Nagappan, G.; Lu, Y. BDNF and synaptic plasticity, cognitive function, and dysfunction. Handb. Exp. Pharmacol. 2015, 220, 223-250. [CrossRef] 
65. Tsai, S.J.; Liao, D.L.; Yu, Y.W.Y.; Chen, T.J.; Wu, H.C.; Lin, C.H.; Cheng, C.Y.; Hong, C.J. A study of the association of (Val66Met) polymorphism in the Brain-derived Neurotrophic Factor gene with alcohol dependence and extreme violence in Chinese males. Neurosci. Lett. 2005, 381, 340-343. [CrossRef] [PubMed]

66. Matsushita, S.; Kimura, M.; Miyakawa, T.; Yoshino, A.; Murayama, M.; Masaki, T.; Higuchi, S. Association study of brain-derived neurotrophic factor gene polymorphism and alcoholism. Alcohol. Clin. Exp. Res. 2004, 28, 1609-1612. [CrossRef]

67. Bresin, K.; Sima Finy, M.; Verona, E. Childhood emotional environment and self-injurious behaviors: The moderating role of the BDNF Val66Met polymorphism. J. Affect. Disord. 2013, 150, 594-600. [CrossRef] [PubMed]

68. Duma, D.; Fernandes, D.; Bonini, M.G.; Stadler, K.; Mason, R.P.; Assreuy, J. NOS-1-derived NO is an essential triggering signal for the development of systemic inflammatory responses. Eur. J. Pharmacol. 2011, 668, 285-292. [CrossRef]

69. Retz, W.; Reif, A.; Freitag, C.M.; Retz-Junginger, P.; Rösler, M. Association of a functional variant of neuronal nitric oxide synthase gene with self-reported impulsiveness, venturesomeness and empathy in male offenders. J. Neural Transm. 2010, 117, 321-324. [CrossRef]

70. Reif, A.; Jacob, C.P.; Rujescu, D.; Herterich, S.; Lang, S.; Gutknecht, L.; Baehne, C.G.; Strobel, A.; Freitag, C.M.; Giegling, I.; et al. Influence of functional variant of neuronal nitric oxide synthase on impulsive behaviors in humans. Arch. Gen. Psychiatry 2009, 66, 41-50. [CrossRef]

71. Yang, C.; Ba, H.; Zhang, W.; Zhang, S.; Zhao, H.; Yu, H.; Gao, Z.; Wang, B. The association of 22 Y chromosome short tandem repeat loci with initiative-aggressive behavior. Gene 2018, 654, 10-13. [CrossRef] [PubMed]

72. Cheng, D.; Hong, C.J.; Liao, D.L.; Tsai, S.J. Association study of androgen receptor CAG repeat polymorphism and male violent criminal activity. Psychoneuroendocrinology 2006, 31, 548-552. [CrossRef]

73. Sjöberg, R.L.; Ducci, F.; Barr, C.S.; Newman, T.K.; Dell'Osso, L.; Virkkunen, M.; Goldman, D. A non-additive interaction of a functional MAO-A VNTR and testosterone predicts antisocial behavior. Neuropsychopharmacology 2008, 33, 425-430. [CrossRef] [PubMed]

74. Hancock, D.B.; Levy, J.L.; Gaddis, N.C.; Glasheen, C.; Saccone, N.L.; Page, G.P.; Bierut, L.J.; Kral, A.H.; Johnson, E.O. Replication of ZNF804A gene variant associations with risk of heroin addiction. Genes Brain Behav. 2015, 14, 635-640. [CrossRef] [PubMed]

75. Tiihonen, J.; Koskuvi, M.; Lähteenvuo, M.; Virtanen, P.L.J.; Ojansuu, I.; Vaurio, O.; Gao, Y.; Hyötyläinen, I.; Puttonen, K.A.; Repo-Tiihonen, E.; et al. Neurobiological roots of psychopathy. Mol. Psychiatry 2020, 25, 3432-3441. [CrossRef] [PubMed]

76. Annerbrink, K.; Jönsson, E.G.; Olsson, M.; Nilsson, S.; Sedvall, G.C.; Anckarsäter, H.; Eriksson, E. Associations between the angiotensin-converting enzyme insertion/deletion polymorphism and monoamine metabolite concentrations in cerebrospinal fluid. Psychiatry Res. 2010, 179, 231-234. [CrossRef]

77. Mahon, P.B.; Zandi, P.P.; Potash, J.B.; Nestadt, G.; Wand, G.S. Genetic association of FKBP5 and CRHR1 with cortisol response to acute psychosocial stress in healthy adults. Psychopharmacology 2013, 227, 231-241. [CrossRef]

78. Chen, B.; Gu, T.; Ma, B.; Zheng, G.; Ke, B.; Zhang, X.; Zhang, L.; Wang, Y.; Hu, L.; Chen, Y.; et al. The CRHR1 gene contributes to genetic susceptibility of aggressive behavior towards others in Chinese southwest han population. J. Mol. Neurosci. 2014, 52, 481-486. [CrossRef]

79. Tang, L.; Chen, Y.; Xiang, Q.; Xiang, J.; Tang, Y.; Li, J. The GCAG Haplotype of the CRHBP Gene May Decrease the Risk for Robbery Behavior among the Han Chinese. Genet. Test. Mol. Biomark. 2020, 24, 436-442. [CrossRef]

80. Palumbo, S.; Mariotti, V.; Iofrida, C.; Pellegrini, S. Genes and Aggressive Behavior: Epigenetic Mechanisms Underlying Individual Susceptibility to Aversive Environments. Front. Behav. Neurosci. 2018, 12, 117. [CrossRef]

81. Iofrida, C.; Palumbo, S.; Pellegrini, S.; Iofrida, C.; Palumbo, S.; Pellegrini, S. Experimental Biology and Medicine Molecular genetics and antisocial behavior: Where do we stand? Exp. Biol. Med. 2014, 239, 1514-1523. [CrossRef] [PubMed]

82. Guillen Gonzalez, D.; Bittlinger, M.; Erk, S.; Müller, S. Neuroscientific and Genetic Evidence in Criminal Cases: A Double-Edged Sword in Germany but Not in the United States? Front. Psychol. 2019, 10, 2343. [CrossRef] [PubMed]

83. O'Mahony, C.; de Paor, A. The use of behavioural genetics in the criminal justice system: A disability \& human rights perspective. Int. J. Law Psychiatry 2017, 54, 16-25. [CrossRef]

84. Brunner, H.G. MAOA deficiency and abnormal behaviour: Perspectives on an association. Ciba Found Symp. 1996, 194, 155-164. [CrossRef] [PubMed]

85. Scurich, N.; Appelbaum, P.S. State v. Yepez: Admissibility and Relevance of Behavioral Genetic Evidence in a Criminal Trial. Psychiatr. Serv. 2021, 72, 853-855. [CrossRef] 